\title{
Arsenic biotransformation in earthworms from contaminated soils
}

\author{
Mark Button* $^{* a, b}$, Gawen R. T. Jenkin ${ }^{b}$, Chris F. Harrington ${ }^{c}$ and Michael J. Watts ${ }^{a}$
}

Two species of arsenic (As) resistant earthworm, Lumbricus rubellus and Dendrodrillus rubidus, 5 their host soils and soil excretions (casts) were collected from 23 locations at a former As mine in Devon, UK. Total As concentrations, measured by ICP-MS, ranged from 255 to $13,080 \mathrm{mg} \mathrm{kg}^{-1}$ in soils, 11 to $877 \mathrm{mg} \mathrm{kg}^{-1}$ in earthworms and 284 to $4221 \mathrm{mg} \mathrm{kg}^{-1}$ in earthworm casts from a subsample of 10 of the 23 investigated sites. The samples were also measured for As speciation using HPLC-ICP-MS to investigate potential As biotransformation pathways. Inorganic arsenate $\left(\mathrm{As}^{\mathrm{V}}\right)$ 10 and arsenite $\left(\mathrm{As}^{\mathrm{III}}\right.$ ) were the only species detected in the soil. $\mathrm{As}^{\mathrm{V}}$ and $\mathrm{As}{ }^{\mathrm{III}}$ were also the dominant species found in the earthworms and cast material together with lower proportions of the organic species methylarsonate $\left(\mathrm{MA}^{\mathrm{V}}\right)$, dimethylarsinate $\left(\mathrm{DMA}^{\mathrm{V}}\right)$, arsenobetaine $(\mathrm{AB})$ and three arsenosugars. Whilst the inorganic As content of the earthworms increased with increasing As body burden, the concentration of organic species remained relatively constant. These results

15 suggest that the biotransformation of inorganic arsenic to organic species does not contribute to As resistance in the sampled earthworm populations. Quantification of As speciation in the soil, earthworms and cast material allows a more comprehensive pathway for the formation of $A B$ in earthworms to be elucidated.

\section{Received (in $X X X, X X X)$ Xth $X X X X X X X X X 200 X$, Accepted Xth $X X X X X X X X X 200 X$ ${ }_{20}$ First published on the web $X$ th $X X X X X X X X X 200 X$ DOI: 10.1039/b000000x}

\section{Introduction}

The chemistry of As in environmental and biological systems is complex. Whilst inorganic As species are the most ${ }_{25}$ prevalent in abiotic environments, the uptake of inorganic As by living organisms can lead to the synthesis of organic As species ${ }^{1}$ through biotransformation. The ubiquitous, epegeic earthworm species L. rubellus and D. rubidus are known to inhabit soils highly contaminated with As at the former mine 30 site of Devon Great Consols (DGC), UK. ${ }^{2-5}$ These earthworms are clearly resistant to As toxicity and several potential coping mechanisms have been proposed, yet the underlying mechanism behind this resistance is unknown. Behavioural adaptation, whereby the earthworm avoids contact with the 35 contaminant, ${ }^{4}$ is unlikely as earthworms from DGC are known to have elevated As body burdens. ${ }^{2,4,5}$ The biotransformation of highly toxic inorganic As to the less toxic organic species arsenobetaine (AB) has been speculated as a mode of mitigating As toxicity in DGC earthworms. ${ }^{2,4}$ An alternative

40 mechanism involves the sequestration of arsenic in the metallothionein-rich chloragogenous tissue which separates the intestine from the coelomic cavity. ${ }^{3}$ With this mechanism it is proposed that inorganic $\mathrm{As}^{\mathrm{III}}$ binds to the sulphur-rich metallothionein thereby sequestering ingested As in a form 45 that is not biologically reactive. ${ }^{6}$

aBritish Geological Survey, KeyworthNottingham, UK NG12 5GG. Email: mbutton@bgs.ac.uk or mwatts@bgs.ac.uk; Fax: +44 0115 9363200; Tel:+44 01159363100

50 bDepartment of Geology, University of Leicester, Leicester, UK. E-mail: grtj1@1eicester.ac.uk or mb274@le.ac.uk Fax: +44 0116 2523981; Tel: +44 01162523934

cSchool of Science and Technology, Nottingham Trent University, Nottingham, UK.
The study of As speciation can provide important information on As biotransformation and toxicity and to date a multitude of organic As species have been identified. ${ }^{7}$ The occurrence of organic As species and their biotransformation pathways are 60 well documented in marine organisms such as crustaceans, molluscs, fish and algae. ${ }^{8-10}$ However, less is known about the occurrence and behaviour of As in terrestrial organisms such as earthworms. ${ }^{11}$ Until recently the organo-arsenic species AB was thought to be restricted to the marine environment, ${ }^{12}$ but ${ }_{65}$ has now been demonstrated in terrestrial fungi ${ }^{13}$ and earthworms. ${ }^{2}, 11,14$ The biotransformation pathway for the formation of $\mathrm{AB}$ in marine organisms is thought to involve the carbohydrate containing As compounds known as arsenosugars. ${ }^{15}$ Langdon et al. (2003) ${ }^{16}$ have proposed a 70 biotransformation pathway for the formation of $\mathrm{AB}$ from ingested inorganic As in earthworms but did not include arsenosugars. It is likely that arsenosugars were not included as they were not observed in arsenic speciation studies in earthworms by the same authors. ${ }^{17}$ In contrast, it is now clear 75 that at least three arsenosugar species (glycerol, phosphate and sulphate) have been detected in earthworms from both uncontaminated and contaminated soils. ${ }^{2,18}$

In light of the uncertainties surrounding the biotransformation pathway for $\mathrm{AB}$ and the role of $\mathrm{AB}$ and 80 other organo-arsenicals in the mechanism underlying the resistance to As toxicity in earthworms from DGC, it seems prudent to examine the issue further. Our previous study ${ }^{2}$ detailed total As data for soils, earthworms and casts from 12 sites at DGC plus As speciation data for the earthworms. This ${ }_{85}$ dataset alone was insufficient to investigate potential As biotransformation pathways. Here we present new data from an additional sampling trip, increasing the number of sampling points to 23, and providing As speciation data for 
the soil, earthworm and casts components. The aims of this study are firstly, to investigate the source of $\mathrm{AB}$ and arsenosugars in earthworms from DGC by determining the As speciation of the host soil, earthworm and earthworm casts. s Secondly, to elucidate a more comprehensive biotransformation pathway for the formation of $\mathrm{AB}$ in earthworms and thirdly, to examine further the role of $\mathrm{AB}$ and arsenosugars in the resistance to As of earthworms from DGC.

\section{Methods}

\section{${ }_{10}$ Study site}

DGC is one of many former mining sites in south-west England situated by the River Tamar in the Tavistock district of Devon (SX 426 735). In the 1870s, DGC along with half a dozen mines from the Callington and Tavistock area were the

15 source of an estimated 50 percent of the world's arsenic production. ${ }^{19}$ Arsenic concentrations found in soils surrounding the mine vary significantly depending on their proximity to the main tailings, ranging from $204-34,000 \mathrm{mg}$ $\mathrm{kg}^{-1} \cdot 2,19,20$

20

\section{Reagents and standards}

All reagents used were analytical grade or better quality. All aqueous solutions were prepared using deionised water (18.2 $\mathrm{M} \Omega$ Millipore, UK). Inorganic $\mathrm{As}^{\mathrm{III}}$ and $\mathrm{As}^{\mathrm{V}}$ (Fisher, UK), 25 organic methylarsonate $\left(\mathrm{MA}^{\mathrm{V}}\right.$, Sigma-Aldrich, UK), dimethylarsinate $\left(\mathrm{DMA}^{\mathrm{V}}\right.$, Greyhound, UK) and $\mathrm{AB}$ (LGC, UK) were used for the preparation of standards for arsenic speciation analysis. Four arsenosugar compounds were isolated from marine algae as reported previously ${ }^{2}$. These

30 arsenosugar compounds were prepared according to methods published by Madsen et al. $(2000)^{10}$ and were used for the identification of arsenosugars in earthworm extracts. Figure 1 illustrates the structure of the four arsenosugar compounds. Methanol (Fisher Scientific, UK), phosphoric acid and 35 ascorbic acid (BDH Aristar, UK) were employed during sample extraction. Ammonium nitrate (Sigma-Aldrich, UK) was used as the mobile phase for gradient anion exchange separation of arsenic species. Nitric acid $\left(\mathrm{HNO}_{3} 69 \%\right)$, hydrofluoric acid (HF, 48\%.), perchloric acid $\left(\mathrm{HClO}_{4}, 70 \%\right.$.) 40 and hydrogen peroxide $\left(\mathrm{H}_{2} \mathrm{O}_{2} 30 \%\right)$ (BDH Aristar, UK) were used for the dissolution of earthworms, cast and soil samples

\section{Sample collection and preparation}

Soil and earthworm samples were collected during two 45 sampling trips to DGC in April 2006 and April 2007. The soil surface $(0-20 \mathrm{~cm})$ with an area of approximately $1 \mathrm{~m}^{2}$ was overturned with a spade allowing individual earthworms to be handpicked. Approximately 10 to 25 mature earthworms (clitellum present) were collected at each sampling point. $L$. so rubellus and $D$. rubidus specimens were identified and separated using a dichotomous earthworm key, ${ }^{21}$ thoroughly rinsed with deionised water and placed in ventilated plastic tubes with moist filter paper to begin depuration of the gut contents. Filter papers were changed daily to prevent
55 coprophagy and allow collection of the cast material. Earthworms were depurated for a minimum of 48 hours, since shorter times were unlikely to remove all soil particles in larger species such as L. rubellus. ${ }^{16}$ Depuration was halted when no more cast material was deposited on the filter paper. 60 In addition, a sub-sample of depurated earthworms were dissected and the gut contents examined under a microscope to ensure depuration was complete. Depurated earthworms were dispatched humanely (rapid freezing) before being dried along with the cast material (collected during depuration) in a

${ }_{65}$ low temperature oven $\left(50{ }^{\circ} \mathrm{C}\right)$ then homogenised in a ceramic pestle and mortar. A composite soil sample from the overturned surface (approximately $1 \mathrm{~kg}$ ) was collected at each site, placed in a sealed paper bag and dried at room temperature. Soils were disaggregated in a ceramic pestle and 70 mortar, sieved to $<250 \mu \mathrm{m}$, homogenised by shaking then stored in airtight containers prior to analysis.

\section{Sample digestion}

\section{Soils and casts}

75 Homogenised soils and earthworm casts $(0.25$ g) were prepared for total elemental measurements by ICP-MS based on a mixed acid digestion approach $\left(\mathrm{HF} / \mathrm{HNO}_{3} / \mathrm{HClO}_{4}\right)^{22}$ Samples were weighed directly into to polytetrafluoroethylene (PTFA) Savillex ${ }^{\circledR}$ vials, acids added and heated on a 80 temperature programmable graphite hot-block $\left(80{ }^{\circ} \mathrm{C}\right.$ for 8 hrs, $100{ }^{\circ} \mathrm{C}$ for $2 \mathrm{hrs}, 120^{\circ} \mathrm{C}$ for $1 \mathrm{hr}, 140{ }^{\circ} \mathrm{C}$ for $3 \mathrm{hrs}, 160^{\circ} \mathrm{C}$ for $4 \mathrm{hrs}$ ). Once digested and evaporated the sample was taken up in $2.5 \mathrm{ml}$ of $\mathrm{HNO}_{3}$, heated at $50{ }^{\circ} \mathrm{C}$ for 30 minutes, left to cool then treated with $1 \mathrm{ml} \mathrm{H}_{2} \mathrm{O}_{2}$ before being made up 85 to volume $(25 \mathrm{ml})$ with deionised water to give a final solution of $5 \% \mathrm{HNO}_{3}$ for analysis by ICP-MS. Certified reference materials were included with each batch of soil and cast digestions as a measure of quality control. These were NIST CRM 2710 Montana Soil I and NIST CRM 2711 ${ }_{90}$ Montana Soil II with certified As values of $626 \pm 38 \mathrm{mg} \mathrm{kg}^{-1}$ and $105 \pm 8 \mathrm{mg} \mathrm{kg}^{-1}$ respectively.

\section{Earthworms}

Microwave assisted (MARS 5, CEM, UK) dissolution of the 95 earthworms using a closed vessel system was performed on $0.1 \mathrm{~g}$ of earthworm homogenate (dry weight). To each vessel $10 \mathrm{ml} \mathrm{HNO}_{3}$ and $100 \mu \mathrm{HF}$ was added before standing for 30 minutes then microwaving. Following an initial heating program (ramp to $100{ }^{\circ} \mathrm{C}$ over 5 minutes then hold for 5 100 minutes, ramp to $200{ }^{\circ} \mathrm{C}$ over 5 minutes then hold for 5 minutes) the vessels were allowed to $\operatorname{cool}\left(<50^{\circ} \mathrm{C}\right)$ and then 1 $\mathrm{ml}$ of $\mathrm{H}_{2} \mathrm{O}_{2}$ was added. The vessels were sealed and the microwave cycle repeated. After cooling the sample solutions were transferred to PTFA containers and evaporated to 105 dryness on a hotplate $\left(100{ }^{\circ} \mathrm{C}\right)$. Samples were reconstituted by the addition of $2 \mathrm{ml}$ of $50 \% \mathrm{v} / \mathrm{v} \mathrm{HNO}_{3}$, heated at $50{ }^{\circ} \mathrm{C}$ for 30 minutes and then made up to $10 \mathrm{ml}$ with deionised water. The procedure was monitored using a certified reference material, CRM 627 tuna fish (BCR, Brussels) with a certified 
As value of $4.8 \pm 0.3 \mathrm{mg} \mathrm{kg}^{-1}$.

\section{Sample extraction}

\section{Soils and casts}

${ }_{5}$ Extraction of As from soils and earthworm casts was performed using a method developed previously. ${ }^{23}$ In brief, $0.2 \mathrm{~g}$ of each prepared sample was accurately weighed into 30 $\mathrm{ml}$ round-bottom Nalgene ${ }^{\circledR}$ extraction vessels, $10 \mathrm{ml}$ of a $1 \mathrm{M}$ phosphoric acid / $0.5 \mathrm{M}$ ascorbic acid mixture was then added 10 and the lids securely fastened. The extraction vessels were then attached to an orbital shaker and extracted for 4 hours at $200 \mathrm{rpm}$. Extractions were conducted in the dark to avoid speciation changes due to UV radiation. Following shaking the extraction vessels were placed for 5 minutes in a sonic 15 bath ${ }^{24}$, centrifuged for 15 minutes at $2000 \mathrm{rpm}$ and the supernatant carefully removed. Only one extraction step was employed as any additional arsenic contained in the second and subsequent extractions has been shown to be accountable to the residual dissolved arsenic carried over from previous 20 extractions. ${ }^{25}$ Sample extracts were stored in the dark at $<4$ ${ }^{\circ} \mathrm{C}$. All speciation analyses were performed within 24 hours of extraction, the maximum time period in which species are known to remain stable ${ }^{26}$.

\section{${ }_{25}$ Earthworms}

Homogenised earthworm powder $(0.25 \mathrm{~g})$ was weighed directly into $30 \mathrm{ml}$ round bottom Nalgene ${ }^{\circledR}$ extraction vessels. $10 \mathrm{ml}$ of methanol:water $(1: 1 \mathrm{v} / \mathrm{v})$ was then added and the tubes shaken on an orbital shaker at $175 \mathrm{rpm}$ for 4 hours. The 30 extracts were centrifuged at $3000 \mathrm{rpm}$ for 10 minutes and the supernatant transferred to $10 \mathrm{ml}$ polypropylene bottles. The methanol was evaporated off using a rotary evaporator before freeze drying. The freeze-dried residue was reconstituted in $10 \mathrm{ml}$ of deionised water and analysed immediately. Prior to 35 extraction of earthworm samples, the stability of arsenic species $\left(\mathrm{As}^{\mathrm{III}}, \mathrm{As}^{\mathrm{V}}, \mathrm{MA}^{\mathrm{V}}, \mathrm{DMA}^{\mathrm{V}}\right.$ and $\mathrm{AB}$ ) was established under the extraction conditions employed by separately spiking earthworm powder material with each of the arsenic species. Recoveries of spiked arsenic species were $93 \pm 18 \%$, 40 with no evidence of interconversion between species (particularly between $\mathrm{As}^{\mathrm{III}}$ and $\mathrm{As}^{\mathrm{V}}$ ). Extraction repeatability was monitored using the CRM 627 tuna fish tissue (BCR, Brussels).

\section{Instrumentation}

\section{${ }_{45}$ Total As analysis}

All digested samples and earthworm extracts were determined for As using a Thermoelemental PQ ExCell ICP-MS (Thermo Scientific, UK). The instrument was fitted with a Meinhardt nebuliser and Scott-type spray chamber. The instrument was so tuned using a $1 \mu \mathrm{g} \mathrm{l}^{-1}$ Claritas PPT multi-element tune solution 1 (GlenSpectra, UK). Indium at a concentration of 10 $\mu \mathrm{g}^{-1}$ was used as an internal standard and was added to the sample stream via a T-piece. Soil and cast extracts were determined for As using an Agilent 7500 ICP-MS (Agilent

${ }_{55}$ Technologies, UK). The instrument was fitted with a micro flow concentric nebuliser and quartz Scott-type spray chamber. The instrument response for As was optimised daily. Arsenic detection was performed in collision cell mode using $\mathrm{He}(4 \mathrm{l} / \mathrm{min})$ to minimise potential interferences such as that ${ }_{60}$ of the polyatomic ion ${ }^{40} \mathrm{Ar}+{ }^{35} \mathrm{Cl}$. Tellurium $\left(50 \mu \mathrm{g} \mathrm{l} \mathrm{l}^{-1}\right)$ was used as the internal standard by sample spiking.

\section{Arsenic speciation analysis}

A quaternary pump (GP50-2 HPLC Pump and an AS-50 autosampler; Dionex, USA) was directly coupled to the ICP${ }_{65} \mathrm{MS}$ for measurement of arsenic species by connecting the analytical column to the ICP nebuliser with polyetheretherketone (PEEK) tubing. The two instruments were coupled in such a way that the injection of each sample solution via the autosampler and subsequent measurement was 70 synchronised automatically using the ICP-MS software, enabling reproducible sample injections. Full details of the chromatographic system employed are published elsewhere. ${ }^{2}$ In brief, anion and cation exchange columns (Hamilton PRP$\mathrm{X} 100,250 \mathrm{x} 4 \mathrm{~mm}, 10 \mu \mathrm{m}$ ) and (Hamilton PRP-X200, $250 \mathrm{x}$ $754 \mathrm{~mm}, 10 \mu \mathrm{m})$ respectively, with guard columns of the same material were used to separate the arsenic species present in the sample extracts. Ammonium nitrate was used as the anion exchange mobile phase at $\mathrm{pH} 8.65$ (adjusted with aqueous ammonia) using a gradient elution between 4 and $60 \mathrm{mM}$. ${ }_{80}$ Pyridine (10 $\mathrm{mM}$ isocratic) was used as the cation exchange mobile phase at $\mathrm{pH} 2.26$ (adjusted using conc. formic acid). Earthworm extracts were analysed using the Thermoelemental PQ ExCell ICP-MS as the ion specific detector. Peak areas were calculated from resultant chromatograms using PeakFit ${ }_{85}$ V4.0 chromatography software (Seasolve Software, USA). Soil and cast extracts were analysed using the Agilent 7500 ICP-MS as the ion specific detector. Peak areas were calculated using the Agilent Chemstation LC-MS software (Agilent, UK).

\section{${ }_{90}$ Results}

Soils

Recoveries of total As from CRM 2710 and CRM 2711 of 98 $\pm 4 \%(n=6)$ and $91 \pm 3 \%(n=3)$ of the certified value, respectively, were achieved during the course of the study. ${ }_{95}$ The repeatability precision for the method was additionally assessed using the Thompson Howarth precision control method ${ }^{27}$. Thompson Howarth precision control charts are a simple graphical method for assessing and controlling repeatability precision from a moderate number of duplicated 100 analytical results, in this case $n=21$ duplicate analyses. The repeatability precision was found to exceed the specified Fitness for Purpose (FFP) criteria of $5 \%$ RSD on the duplicate analyses.

${ }_{105}$ Total As levels in the earthworm host soils covered a wide As concentration range from 255 to $13,080 \mathrm{mg} \mathrm{kg}^{-1}$ (Table 1). All the soils are highly contaminated when considered against the current UK Soil Guideline Value (SGV) for As of $20 \mathrm{mg} \mathrm{kg}^{-1}$ 
28. The extraction procedure employed gave a mean recovery of As from the soil of $80 \pm 9 \%$. The mean recovery of As species from the column was $97 \pm 7 \%$ of the total As in the soil extracts. Only inorganic As was present in the soil 5 extracts with the majority being $\mathrm{As}^{\mathrm{V}}$ with small amounts of $\mathrm{As}^{\mathrm{III}}$.

\section{Earthworms}

Recovery of total As from CRM 627 was $96 \pm 7 \%(n=6)$ 10 compared to the certified value. The method precision, expressed as the mean $\%$ difference ( \pm 1 SD), between duplicate earthworm samples was $1.7 \pm 0.9 \% \quad(n=4$ duplicates). The extraction procedure employed gave a mean recovery of $77 \pm 1 \%(\mathrm{n}=3)$ of the total arsenic value for ${ }_{15}$ CRM 627 with a precision, expressed as the mean percentage difference $( \pm 1 \mathrm{SD})$ between duplicate samples, of $2.8 \pm 1.8 \%$ ( $\mathrm{n}=4$ duplicates).

Both species of earthworm had accumulated high levels of As from the host soil with As body burdens ranging from 11 20 to $877 \mathrm{mg} \mathrm{kg}^{-1}$ (Table 2) depending on the As concentration of the host soil. Further details of earthworm species differentiation in terms of As accumulation are presented elsewhere ${ }^{2,5}$. The methanol / water extraction procedure gave variable recoveries of As from prepared earthworm samples

25 (Table 2) with a mean extraction efficiency of $51 \pm 18 \%$. The mean recovery of As species from the column was $90 \pm 23 \%$ of the total $\mathrm{As}$ in the earthworm extracts. Inorganic $\mathrm{As}^{\mathrm{V}}$ was the dominant species extracted followed by $\mathrm{As}^{\mathrm{III}}$. In general $\mathrm{AB}$ was the dominant organic species extracted from the 30 earthworms at an average concentration of $4.2 \pm 3.2 \mathrm{mg} \mathrm{kg}^{-1}$. Similar amounts of $\mathrm{MA}^{\mathrm{V}}$ and $\mathrm{DMA}^{\mathrm{V}}$ were present with the arsenosugars 1, 2 and 4 (Fig. 1) present at the lowest concentrations of the organic species (Table 2). The concentration of inorganic As showed a positive correlation 35 with increasing As body burden in the earthworm (Fig. 3a). In contrast, organic As species do not demonstrate a correlation with increasing As body burden (Fig. 3b). The organic species remain fairly constant (with some fluctuation) across the range of As body burdens observed.

40

\section{Casts}

Total As levels in the earthworm casts ranged from 284 to $4221 \mathrm{mg} \mathrm{kg}^{-1}$ in the 10 available samples, and were similar to total As levels in the corresponding host soil (Tables 1 and 3).

${ }_{45}$ The extraction procedure employed gave mean recoveries for As of $84 \pm 16 \%$ of the total. The mean recovery of As species from the column was $106 \pm 10 \%$ of the total As in the cast extracts. Arsenic speciation in the earthworm casts was similar to that of the host soil with $\mathrm{As}^{\mathrm{V}}$ present as the ${ }_{50}$ dominant species with lower amounts of $\mathrm{As}^{\mathrm{III}}$. In addition the organic As species $\mathrm{AB}, \mathrm{DMA}^{\mathrm{V}}, \mathrm{MA}^{\mathrm{V}}$, sugar 2 and sugar 4 were present at low levels in some of the cast samples with $\mathrm{DMA}^{\mathrm{V}}$ present in higher amounts than the other organic species. No clear relationship was observed between the ${ }_{55}$ organic species present in the earthworm and the subsequent organic species observed in the earthworm cast.

\section{Discussion}

The earthworm species L. rubellus and D. rubidus are able to reside in soils highly contaminated with As at the former mine 60 site DGC, as reported here and in several other studies. ${ }^{2,5,20}$ The As body burdens observed in this study are highly elevated up to a maximum of $877 \mathrm{mg} \mathrm{kg}^{-1}$ (Table 2) yet no harmful physiological side effects are evident or have been reported. These earthworms have clearly developed a ${ }_{65}$ biological mechanism for mitigating the toxic effects of arsenic. The only arsenic species detected in the host soils were inorganic $\mathrm{As}^{\mathrm{III}}$ and $\mathrm{As}{ }^{\mathrm{V}}$, of which $\mathrm{As}^{\mathrm{V}}$ accounted for between 91 and $99 \%$ of the extracted As. This precludes selective bioaccumulation of organic species from the host 70 soil as a potential source of the organic As species observed in the earthworms, as has been suggested previously. ${ }^{11}$ Elsewhere, the biotransformation of $\mathrm{As}^{\mathrm{V}}$ by soil organisms is considered the source of organic As species in the soil environment. ${ }^{15}$ Likewise, this seems a probable source of the 75 organic species observed in earthworms residing at DGC. The biotransformation pathway proposed by Langdon et al. $(2003)^{16}$ attempts to explain As accumulation via the sequestration of high levels of As through $\mathrm{As}^{\mathrm{III}}$-thiol complexing and the formation of $\mathrm{AB}$ via subsequent 80 methylation of the $\mathrm{As}^{\mathrm{III}}$-thiol complexes. This pathway was proposed on the basis that $\mathrm{AB}$ was the only organic As species detected using HPLC-MS, whilst $\mathrm{As}^{\mathrm{III}}$ co-ordinated with sulphur was detected using XAS. This pathway does not take into account the presence of both simple methylated ${ }_{85}$ compounds $\left(\mathrm{MA}^{\mathrm{V}}\right.$ and $\mathrm{DMA}^{\mathrm{V}}$ ) and arsenosugars in the earthworm, as reported here (Table 2) and elsewhere. ${ }^{2,11,18} \mathrm{~A}$ more comprehensive pathway for the formation of both arsenosugars and $\mathrm{AB}$ in earthworms (Fig. 2) can be hypothesised from what is known about the transformations of ${ }_{90}$ As by organisms in marine and freshwater environments. ${ }^{12,} 29$ It is more likely that $\mathrm{As}^{\mathrm{V}}$ ingested from the soil is first converted to $\mathrm{DMA}^{\mathrm{V}}$ via the Challenger pathway ${ }^{15,30}$ (Fig. 2, a) which in turn is converted to arsenosugars through addition of the adenosyl group from $S$-adenosylmethionine (SAM). ${ }^{29}$ 95 This nucleoside then undergoes glycosidation to produce a range of arsenosugars. ${ }^{15,29}$ These arsenosugars are thought to subsequently be converted to $\mathrm{AB}$ along a pathway involving either arsenocholine (AC) or dimethylarsinoylacetate $(D M A A)^{12}$ (Fig. 2, b). The tendency for $A B$ to be more 100 prevalent in earthworm extracts when $\mathrm{DMA}^{\mathrm{V}}$ and the arsenosugars are also present (Table 2 and Fig. 2) provides some evidence for this pathway as the source of $\mathrm{AB}$ in $\mathrm{DGC}$ earthworms.

The synthesis of $\mathrm{AB}$ in earthworms from highly 105 contaminated soils has been speculated as a potential mechanism for mitigating As toxicity. ${ }^{17}$ However, the fact that $\mathrm{AB}$ is only present at low concentrations between 0.5 and 14 $\mathrm{mg} \mathrm{kg}{ }^{-1}$ (Table 2) irrespective of the total As body burden (Fig. 3b) suggests that $\mathrm{AB}$ formation is not a mechanism by 110 which earthworms at DGC mitigate As toxicity. Similar findings were interpreted differently by both Langdon et al. $(2002)^{17}$ who reported similar AB concentrations of $0.3-15$ $\mathrm{mg} \mathrm{kg}^{-1}$ using HPLC-ICP-MS in L. rubellus from contaminated soils and in a previous study. ${ }^{2}$ When the $A B$ 
concentrations were considered as a proportion, rather than actual concentration, against the earthworm total As, a relationship dependent on the earthworm total arsenic was reported. ${ }^{2,}{ }^{17}$ Such interpretation is misleading as consistently 5 low $\mathrm{AB}$ concentrations will inevitably decrease proportionally as total arsenic body burden increases. Concentrations of $\mathrm{AB}$ in $L$. rubellus and $D$. rubidus from uncontaminated soils of 0.3 and $0.5 \mathrm{mg} \mathrm{kg}^{-1}$ respectively have previously been reported, ${ }^{2}$ falling within the range reported for contaminated sites. This 10 reinforces the point that $\mathrm{AB}$ formation in earthworms is independent of total As burdens and not involved in mitigating As toxicity. The resistance is more likely due to a second process (Fig. 2, c) whereby As is thought to be sequestered via binding with sulphur-rich metallothionein 15 within the chloragogenous tissue $\mathrm{e}^{3,17,31}$ allowing the continued accumulation of inorganic As (Fig. 3a) in a form that is not biologically reactive ${ }^{6}$.

The egestion of As in the earthworm cast material was mainly in the form of $\mathrm{As}^{\mathrm{V}}$. The presence of $\mathrm{DMA}^{\mathrm{V}}$ as the 20 dominant organic As species in some of the cast samples (Table 3) may suggest this is the most readily excreted arsenical, although a greater sample size is required to confirm this as $\mathrm{DMA}^{\mathrm{V}}$ was not present in all samples. Low levels of arsenosugars were detected in some of the cast 25 samples (Table 3). Trace levels of arsenosugars in earthworm casts were reported in the study by Geiszinger et al. (2002). ${ }^{18}$ However, the authors were unable to provide quantitative estimates of the concentration of arsenosugars in the earthworm casts as the methanol / water extraction was only $300.7 \%$ efficient. The mean extraction efficiency of $84 \pm 16 \%$ presented here allows the speciation data for casts samples to be considered quantitative. Only very low levels of $\mathrm{AB}(0.1$ $\mathrm{mg} \mathrm{kg}^{-1}$ ) were present in the cast material (Table 3) suggesting this arsenical is less readily excreted than either $\mathrm{DMA}^{\mathrm{V}}$ (up to $357.1 \mathrm{mg} \mathrm{kg}^{-1}$ ) or the arsenosugars (up to $0.7 \mathrm{mg} \mathrm{kg}^{-1}$ ). This precludes egestion of $\mathrm{AB}$ as a possible mechanism behind the consistently low levels of this organic As species observed in earthworms with elevated As body burdens.

The use of solvent extraction separation techniques that 40 ignore the results of in-situ studies are potentially misleading with respect to As speciation. As ${ }^{\mathrm{III}}$-sulphur complexes were detected in DGC earthworms by Langdon et al. $(2002)^{17}$ when the in-situ speciation technique X-ray Absorption Spectroscopy (XAS) was employed. It is possible that the 45 solvent extraction method employed in this study may cause dissociation of $\mathrm{As}^{\mathrm{III}}$-sulphur complexes leading to the detection $\mathrm{As}^{\mathrm{III}}$ alone. This would provide a possible explanation for the high levels of $\mathrm{As}^{\mathrm{III}}$ determined in earthworm extracts in this study. The reason for the presence

50 of $\mathrm{AB}$ at consistently low concentrations irrespective of total body burden is not clear. It would be useful to investigate $A B$ synthesis in earthworms from soils with very low As concentrations to see if a minimum level of $\mathrm{AB}$ is synthesised, perhaps above soil levels, which would clarify its role in the ${ }_{55}$ physiological processes of earthworms. It has been suggested that $\mathrm{AB}$ may act as an analogue for the osmoregulant cysteine betaine in marine animals ${ }^{32}$. Whether this process is involved in the regulation of $\mathrm{AB}$ in earthworm populations at $\mathrm{DGC}$ requires further investigation. 60

\section{Conclusions}

The definitive biotransformation pathway for As in earthworms is still unclear. The data presented here suggests that the organic species are a product of As biotransformation ${ }_{65}$ within the worm itself as no organic species were present in the soil. The biotransformation of $\mathrm{As}^{\mathrm{V}}$ to $\mathrm{AB}$ is not likely involved in the resistance to As toxicity in earthworm populations at $\mathrm{DGC}$ as $\mathrm{AB}$ concentrations are consistently low and independent of earthworm total As. It is more likely that 70 there are two process of arsenic biotransformation occurring in these As resistant earthworms. Firstly, the sequestration of inorganic As in a form that is not biologically reactive such as binding with sulphur-rich metallothionein within the chloragogenous tissue providing the mechanism for As 75 resistance and secondly, the biotransformation of inorganic $\mathrm{As}^{\mathrm{V}}$ along a pathway comparable to those proposed for marine and freshwater organisms as the source of the observed organic arsenic compounds.

\section{Acknowledgments}

Funding for this research was provided by the British Geological Survey University Funding Initiative (BUFI). We also thank the University of Leicester Department of Geology for facilitating the mesocosm experiment and the Tavistock 85 estate for allowing us to collect samples.

\section{References}

1. A. Raab, A. A. Meharg, M. Jaspars, D. R. Genney and J. Feldmann, J. Anal. At. Spectrom., 2004, 19, 183-190.

90 2. M. J. Watts, M. Button, T. S. Brewer, G. R. T. Jenkin and C. F. Harrington, J. Environ. Monit., 2008, 10, 753-759.

3. A. J. Morgan, Winters, C and Yarwood, A., Cell Biology International, 1994, 18, 911-914.

4. C. J. Langdon, T. G. Piearce, S. Black and K. T. Semple, Soil Biol. 95 Biochem., 1999, 31, 1963-1967.

5. M. Button, M. J. Watts, M. Cave, C. F. Harrington and G. R. T. Jenkin, Environ. Geochem. Health, 2008, In Press, DOI: 10.1007/s10653-10008-19208-10653.

6. M. G. Vijver, C. A. M. Van Gestel, R. P. Lanno, N. M. Van Straalen 100 and W. J. G. M. Peijnenburg, Environ. Sci. Technol., 2004, 38, 4705-4712.

7. S. A. Pergantis, W. Winnik and D. Betowski, J. Anal. At. Spectrom., 1997, 12, 531-536.

8. U. Nørum, V. W. M. Lai, S. A. Pergantis and W. R. Cullen, J. $105 \quad$ Environ. Monit., 2005, 7, 122-126.

9. P. J. Peshut, R. J. Morrison and B. A. Brooks, Chemosphere, 2008, 71, 484-492.

10. A. D. Madsen, W. Goessler, S. N. Pedersen and K. A. Francesconi, J. Anal. At. Spectrom., 2000, 15, 657-662.

110 11. A. Geiszinger, W. Goessler, D. Kuehnelt, W. Kosmus and K. Francesconi, Environ. Sci. Technol., 1998, 32, 2238-2243. 
12. A. W. Ritchie, J. S. Edmonds, W. Goessler and R. O. Jenkins, FEMS Microbiol. Lett., 2004, 235, 95-99.

13. M. Slekovec, W. Goessler and K. J. Irgolic, Chem. Speciation Bioavailability, 1999, 11, 115-123.

5 14. C. J. Langdon, T. G. Piearce, K. T. Semple, J. Feldmann and A. A. Meharg, Environ. Toxicol. Chem., 2003, 22, 1302-1308.

15. G. S. Smith, PhD, Queen's University, 2007.

16. C. J. Langdon, T. G. Piearce, A. A. Meharg and K. T. Semple, Environ. Pollut., 2003, 124, 361-373.

10 17. C. J. Langdon, A. A. Meharg, J. Feldmann, T. Balgar, J. Charnock, M. Farquhar, T. G. Piearce, K. T. Semple and J. CotterHowells, J. Environ. Monit. , 2002, 4, 603-608.

18. A. Geiszinger, W. Goessler and W. Kosmus, Appl. Organomet. Chem. , 2002, 16, 473-476.

15 19. B. A. Klinck, B. Palumbo, M. R. Cave and J. Wragg, Arsenic dispersal and bioaccessibility in mine contaminated soils: a case study from an abandoned arsenic mine in Devon, UK, Research Report RR/04/003, British Geological Survey, Nottingham, 2002.

20 20. C. J. Langdon, T. G. Piearce, A. A. Meharg and K. T. Semple, Soil Biol. Biochem., 2001, 33, 1239-1244.

21. Worm Watch Canada: Key to Reproductively Mature Earthworms From: http://www.naturewatch.ca. Retrieved on February 22, 2007.

25 22. K. A. Green, S. R. Chenery, T. S. Barlow, H. Taylor and J. M. Cook, 13th Biennial National Atomic Spectroscopy Symposium, 2006, Glasgow, UK.

23. M. Button and M. J. Watts, British Geological Survey, 2008, $\mathrm{IR} / 08 / 050$.

30 24. I. Pizarro, M. Gomez, C. Camara and M. A. Palacios, Anal. Chim. Acta, 2003, 495, 85-98.

25. K. A. Francesconi, Appl. Organomet. Chem., 2003, 17, 682-683.

26. M. J. Ruiz-Chancho, R. Sabé, J. F. López-Sánchez, R. Rubio and P. Thomas, Microchim. Acta, 2005, 151, 241-248.

35 27. Royal Society of Chemistry: A simple fitness-for-purpose control chart based on duplicate results obtained from routine test materials from http://www.rsc.org/images/brief9 tcm1825951.pdf. Retrieved on February 22, 2008.

28. Defra, The contaminated land exposure assessment model (CLEA):

$40 \quad$ technical basis and algorithms CLR10., 2002, Environment Agency.

29. L. A. Murray, Raab, A., Marr, I.L., Feldmann, J. , Appl. Organomet. Chem., 2003, 17, 669-674.

30. D. J. Thomas, S. B. Waters and M. Styblo, Toxicol. Appl. Pharmacol., 2004, 198, 319-326.

31. S. R. Sturzenbaum, O. Georgiev, A. J. Morgan and P. Kille, Environ. Sci. Technol., 2004, 38, 6283-6289.

32. H. Amlund and M. H. G. Berntssen, Comparative Biochemistry and Physiology Part C: Toxicology \& Pharmacology, 2004, 138, 507-514. 
Table 1: Total and speciation data for As in soil samples. Extraction efficiency based on extracted arsenic as a percentage of total As. Column recovery refers to As species recovered from the column as a percentage of the total As in the extract. nd = no data

\begin{tabular}{|c|c|c|c|c|c|c|}
\hline \multirow{2}{*}{$\begin{array}{l}\text { Site } \\
\text { id }\end{array}$} & \multirow{2}{*}{$\begin{array}{c}\text { Total } \\
\text { As } \\
\left(\mathrm{mg} \mathrm{kg}^{-1}\right)\end{array}$} & \multirow{2}{*}{$\begin{array}{c}\text { Extracted } \\
\text { As } \\
\left(\mathrm{mg} \mathrm{kg}^{-1}\right) \\
\end{array}$} & \multirow{2}{*}{$\begin{array}{c}\text { Extraction } \\
\text { efficiency } \\
(\%)\end{array}$} & \multicolumn{2}{|c|}{$\begin{array}{l}\text { Speciated As } \\
\left(\mathrm{mg} \mathrm{kg}^{-1}\right)\end{array}$} & \multirow{2}{*}{$\begin{array}{c}\text { Column } \\
\text { Recovery } \\
(\%)\end{array}$} \\
\hline & & & & $\mathrm{As}^{\mathrm{III}}$ & $\mathrm{As}^{\mathrm{V}}$ & \\
\hline D1 & 2980 & 2365 & 79 & 23 & 2177 & 93 \\
\hline D2 & 1573 & 1113 & 71 & 5.8 & 973 & 88 \\
\hline D3 & 1005 & 771 & 77 & 35 & 734 & 100 \\
\hline D4 & 255 & 201 & 79 & 2.8 & 177 & 89 \\
\hline D6 & 13080 & 12434 & 95 & 76 & 10442 & 85 \\
\hline D7 & 372 & 400 & 108 & 36 & 362 & 100 \\
\hline D9 & 284 & 222 & 78 & 5.4 & 221 & 102 \\
\hline D10 & 439 & 326 & 74 & 4.8 & 302 & 94 \\
\hline D11 & 289 & 237 & 82 & 7.5 & 217 & 95 \\
\hline D12 & 5141 & 3713 & 72 & 89 & 3760 & 95 \\
\hline D13 & 2871 & 2484 & 87 & 39 & 2359 & 97 \\
\hline D15 & 913 & 742 & 81 & 5.6 & 712 & 97 \\
\hline D16 & 3995 & 3184 & 80 & 95 & 3044 & 99 \\
\hline D17 & 622 & 489 & 79 & 4.4 & 450 & 93 \\
\hline D18 & 1567 & 1188 & 76 & 19 & 1100 & 94 \\
\hline D19 & 1173 & 1136 & 97 & 12 & 905 & 81 \\
\hline D20 & 6308 & 4572 & 72 & 62 & 5154 & 109 \\
\hline D21 & 480 & 406 & 85 & 12 & 393 & 100 \\
\hline D23 & 275 & 211 & 77 & 12 & 192 & 96 \\
\hline D24 & 1306 & nd & nd & nd & nd & nd \\
\hline D25 & 9025 & 8097 & 90 & 111 & 8336 & 98 \\
\hline D26 & 5760 & 4055 & 70 & 45 & 4279 & 104 \\
\hline D27 & 427 & 298 & 70 & 4.9 & 301 & 97 \\
\hline
\end{tabular}


Table 2: Total and speciation data for As in earthworm samples. Extraction efficiency based on extracted arsenic as a percentage of total As. Column recovery refers to As species recovered from the column as a percentage of the total As in the extract. $<$ LOD $=$ not detected or below limit of detection.

\begin{tabular}{|c|c|c|c|c|c|c|c|c|c|c|c|c|c|}
\hline \multirow{2}{*}{$\begin{array}{c}\text { Site } \\
\text { id }\end{array}$} & \multirow{2}{*}{$\begin{array}{c}\text { Earthworm } \\
\text { species }\end{array}$} & \multirow{2}{*}{$\begin{array}{c}\text { Total } \\
\text { As } \\
\left(\mathrm{mg} \mathrm{kg}^{-1}\right) \\
\end{array}$} & \multirow{2}{*}{$\begin{array}{c}\text { Extracted } \\
\text { As } \\
\left(\mathrm{mg} \mathrm{kg}^{-1}\right) \\
\end{array}$} & \multirow{2}{*}{$\begin{array}{c}\text { Extraction } \\
\text { Efficiency } \\
(\%) \\
\end{array}$} & \multicolumn{8}{|c|}{ Speciated As (mg kg $\left.{ }^{-1}\right)$} & \multirow{2}{*}{$\begin{array}{c}\text { Column } \\
\text { Recovery } \\
(\%)\end{array}$} \\
\hline & & & & & $\mathbf{A B}$ & $\mathrm{As}^{\mathrm{III}}$ & DMA $^{\text {V }}$ & $\mathbf{M A}^{\mathbf{V}}$ & $\mathrm{As}^{\mathrm{V}}$ & $\begin{array}{c}\text { sugar } \\
1 \\
\end{array}$ & $\begin{array}{c}\text { sugar } \\
2 \\
\end{array}$ & $\begin{array}{c}\text { Sugar } \\
\mathbf{4} \\
\end{array}$ & \\
\hline D11B & L. rubellus & 11 & 3.6 & 32 & 0.5 & 0.7 & $<\mathrm{LOD}$ & $<\mathrm{LOD}$ & 2.4 & 0.3 & 0.3 & $<\mathrm{LOD}$ & 115 \\
\hline D10 & L. rubellus & 40 & 11 & 27 & 1.5 & 2.8 & $<\mathrm{LOD}$ & 0.1 & 7.2 & 0.1 & nd & $<\mathrm{LOD}$ & 109 \\
\hline D24 & L. rubellus & 54 & 15 & 28 & 0.8 & 5 & $<\mathrm{LOD}$ & 0.3 & 11 & 0.1 & $<\mathrm{LOD}$ & $<\mathrm{LOD}$ & 114 \\
\hline D12 & L. rubellus & 203 & 163 & 81 & 2.6 & 42 & 0.1 & 0.8 & 50 & 0.3 & nd & 0.7 & 59 \\
\hline D2 & L. rubellus & 257 & 161 & 63 & 4.8 & 47 & 0.2 & 0.5 & 44 & 0.3 & nd & 0.6 & 60 \\
\hline D18 & L. rubellus & 355 & 186 & 52 & 2.4 & 82 & 10 & 10 & 104 & 0.3 & nd & 0.2 & 113 \\
\hline D6 & L. rubellus & 359 & 150 & 42 & 1.9 & 40 & $<\mathrm{LOD}$ & 1.3 & 40 & 0.2 & nd & 1 & 56 \\
\hline D20 & L. rubellus & 385 & 127 & 33 & 1.4 & 24 & 2.7 & 4.2 & 77 & $<\mathrm{LOD}$ & nd & $<\mathrm{LOD}$ & 86 \\
\hline D13 & L. rubellus & 571 & 366 & 64 & 4 & 149 & 0.1 & 0.5 & 61 & 0.8 & nd & 1 & 59 \\
\hline D1 & L. rubellus & 595 & 215 & 36 & 2.2 & 55 & 0.2 & 0.6 & 51 & 0.5 & nd & 1 & 52 \\
\hline D26 & L. rubellus & 607 & 345 & 57 & 3.4 & 39 & 1.5 & 2.8 & 289 & 0.3 & $<\mathrm{LOD}$ & $<\mathrm{LOD}$ & 98 \\
\hline D25 & L. rubellus & 877 & 430 & 49 & 7.8 & 155 & $<\mathrm{LOD}$ & 1.2 & 335 & 0.4 & $<\mathrm{LOD}$ & $<\mathrm{LOD}$ & 116 \\
\hline D27 & D. rubidus & 15 & 9 & 60 & 5.4 & 1.8 & $<\mathrm{LOD}$ & $<\mathrm{LOD}$ & 2.1 & 0.3 & 0.3 & $<\mathrm{LOD}$ & 110 \\
\hline D7 & D. rubidus & 17 & 9.3 & 54 & 3.4 & 4.3 & 0.1 & 0.1 & 1.6 & 0.3 & 0.1 & $<\mathrm{LOD}$ & 105 \\
\hline D9 & D. rubidus & 18 & 14 & 77 & 5 & 5.9 & 0.1 & 0.1 & 1 & 0.7 & 0.1 & 0 & 94 \\
\hline D4 & D. rubidus & 19 & 5.9 & 31 & 2.9 & 0.3 & $<\mathrm{LOD}$ & 0.1 & 1.8 & 0.2 & 0.4 & $<\mathrm{LOD}$ & 97 \\
\hline D23 & D. rubidus & 19 & 9 & 47 & 2.1 & 3 & 0.1 & 0.1 & 3.9 & 0.5 & 0.2 & $<\mathrm{LOD}$ & 108 \\
\hline D11A & D. rubidus & 37 & 20 & 52 & 1.7 & 5.6 & $<\mathrm{LOD}$ & $<\mathrm{LOD}$ & 2.5 & 0.4 & 0.1 & $<\mathrm{LOD}$ & 53 \\
\hline D21 & D. rubidus & 61 & 27 & 44 & 2.4 & 7.2 & 3.7 & 0.6 & 11 & 0.3 & 0.2 & $<\mathrm{LOD}$ & 95 \\
\hline D15 & D. rubidus & 73 & 54 & 73 & 6 & 33 & 0.3 & 0.3 & 14 & 0.2 & 0.8 & 0.2 & 102 \\
\hline D17 & D. rubidus & 132 & 94 & 71 & 9.7 & 11 & 22 & 6.9 & 36 & 0.4 & 0.3 & 0.1 & 91 \\
\hline D19 & D. rubidus & 164 & 53 & 32 & 7 & 7.3 & 4.9 & 0.9 & 34 & 0.3 & 0.8 & $<\mathrm{LOD}$ & 104 \\
\hline D3 & D. rubidus & 317 & 260 & 82 & 7.7 & 93 & 0.1 & 0.1 & 41 & 0.2 & 0.1 & 0.5 & 55 \\
\hline D16 & D. rubidus & 737 & 237 & 32 & 14 & 68 & 1.8 & 1.5 & 159 & 0.8 & 0.3 & $<\mathrm{LOD}$ & 103 \\
\hline
\end{tabular}


Table 3: Total and speciation data for As in cast samples. Extraction efficiency based on extracted arsenic as a percentage of total As. Column recovery refers to As species recovered from the column as a percentage of the total As in the extract. $<\mathrm{LOD}=$ not detected or below limit of detection.

\begin{tabular}{|c|c|c|c|c|c|c|c|c|c|c|c|}
\hline \multirow[b]{2}{*}{$\begin{array}{c}\text { Site } \\
\text { id }\end{array}$} & \multirow{2}{*}{$\begin{array}{c}\text { Total } \\
\text { As } \\
\left(\mathrm{mg} \mathrm{kg}^{-1}\right)\end{array}$} & \multirow{2}{*}{$\begin{array}{c}\text { Extracted } \\
\text { As } \\
\left(\mathrm{mg} \mathrm{kg}^{-1}\right) \\
\end{array}$} & \multirow{2}{*}{$\begin{array}{c}\text { Extraction } \\
\text { efficiency } \\
(\%)\end{array}$} & \multicolumn{7}{|c|}{ Speciated As (mg kg $\left.{ }^{-1}\right)$} & \multirow{2}{*}{$\begin{array}{c}\text { Column } \\
\text { Recovery } \\
(\%)\end{array}$} \\
\hline & & & & AB & $\mathbf{A s}^{\mathrm{III}}$ & DMA $^{\mathrm{V}}$ & $\mathbf{M A}^{\mathbf{V}}$ & $\mathrm{As}^{\mathrm{V}}$ & $\begin{array}{c}\text { sugar } \\
2\end{array}$ & $\begin{array}{c}\text { sugar } \\
4\end{array}$ & \\
\hline$\overline{\mathrm{D} 1}$ & 2488 & 2326 & 94 & $<\mathrm{LOD}$ & 72 & $<$ LOD & 0.3 & 2204 & $<\mathrm{LOD}$ & $<\mathrm{LOD}$ & 98 \\
\hline D3 & 994 & 908 & 91 & $<\mathrm{LOD}$ & 92 & 0.8 & 0.2 & 864 & 0.3 & 0.7 & 105 \\
\hline $\mathrm{D} 10$ & 284 & 244 & 86 & $<\mathrm{LOD}$ & 12 & $<\mathrm{LOD}$ & $<\mathrm{LOD}$ & 236 & $<\mathrm{LOD}$ & $<\mathrm{LOD}$ & 101 \\
\hline D11A & 291 & 204 & 70 & 0.1 & 17 & $<\mathrm{LOD}$ & 0.1 & 231 & $<\mathrm{LOD}$ & 0.1 & 122 \\
\hline $\mathrm{D} 12$ & 1173 & 1420 & 121 & $<\mathrm{LOD}$ & 107 & $<\mathrm{LOD}$ & 0.7 & 1344 & 0.1 & 0.5 & 102 \\
\hline D16 & 2290 & 1960 & 86 & 0.1 & 66 & 5.4 & 0.1 & 1940 & $<$ LOD & 0.4 & 103 \\
\hline D19 & 1203 & 1041 & 87 & 0.1 & 20 & $<\mathrm{LOD}$ & 0.2 & 1001 & $<$ LOD & $<$ LOD & 98 \\
\hline D20 & 2359 & 1465 & 62 & $<$ LOD & 27 & 5.7 & 0.2 & 1445 & $<$ LOD & $<$ LOD & 101 \\
\hline $\mathrm{D} 21$ & 421 & 292 & 69 & $<\mathrm{LOD}$ & 12 & 7.1 & $<$ LOD & 351 & $<\mathrm{LOD}$ & $<\mathrm{LOD}$ & 127 \\
\hline D26 & 4221 & 3333 & 79 & 0.1 & 60 & $<$ LOD & 0.5 & 3473 & $<\mathrm{LOD}$ & $<\mathrm{LOD}$ & 106 \\
\hline
\end{tabular}<smiles>[R]CC(O)COC1OC(C[As](C)(C)=O)C(O)C1O</smiles>

Arsenosugar 1 (glycerol) $\quad \mathrm{R}=\mathrm{OH}$

Arsenosugar 2 (phosphate) $\mathrm{R}=\mathrm{OP}(\mathrm{O})(\mathrm{OH}) \mathrm{OCH}_{2} \mathrm{CH}(\mathrm{OH}) \mathrm{CH}_{2} \mathrm{OH}$

Arsenosugar 3 (sulphonate) $\quad \mathrm{R}=\mathrm{SO}_{3} \mathrm{H}$

Arsenosugar 4 (sulphate) $\quad \mathrm{R}=\mathrm{OSO}_{3} \mathrm{H}$

Figure 1: Structures of the four arsenosugars. 
(c)

(a)

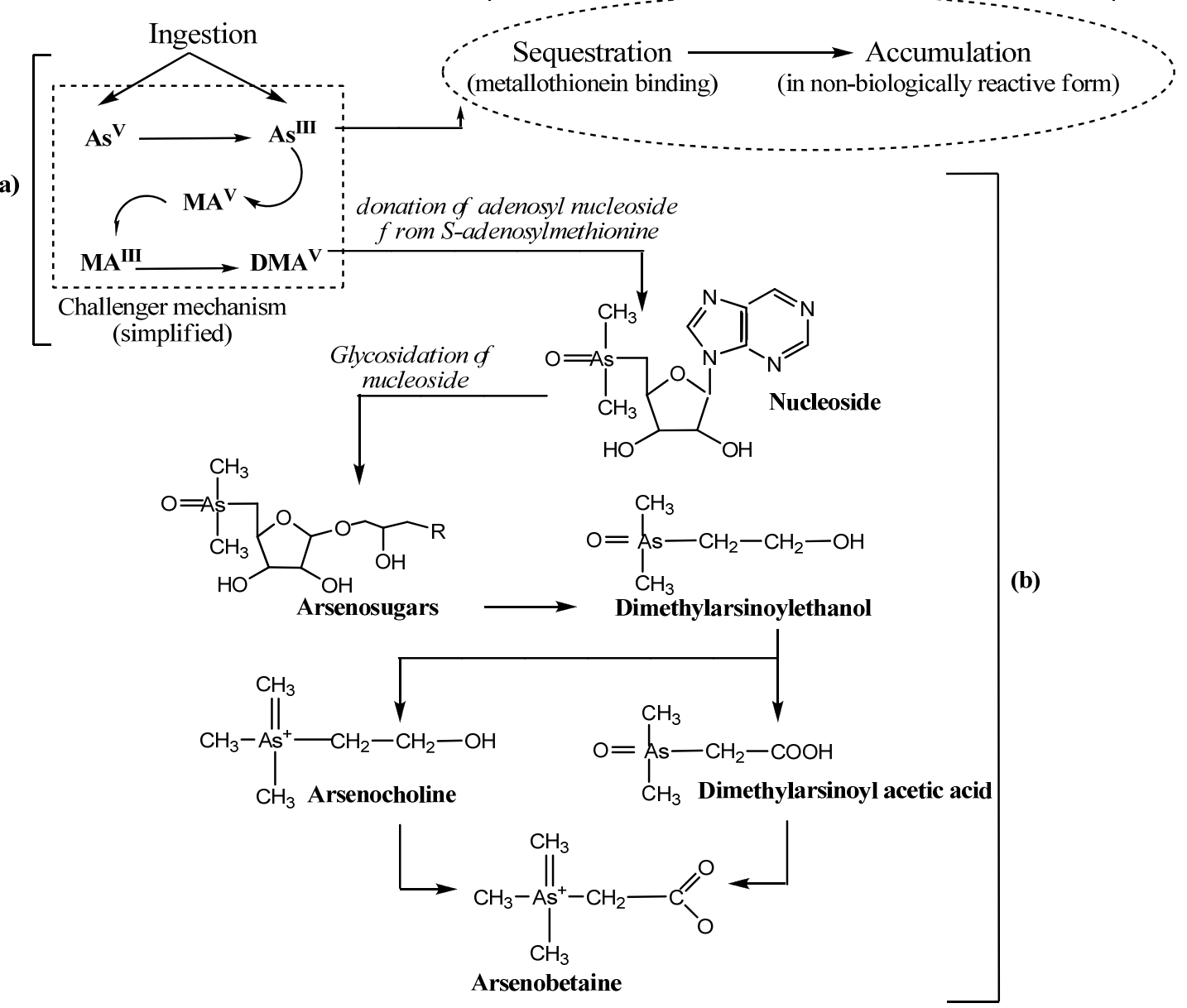

Figure 2: Speculative pathway for the biotransformation (a/b) and accumulation (c) of As in resistant earthworms from DGC. Adapted from ${ }^{12,15,16,29 .}$ 

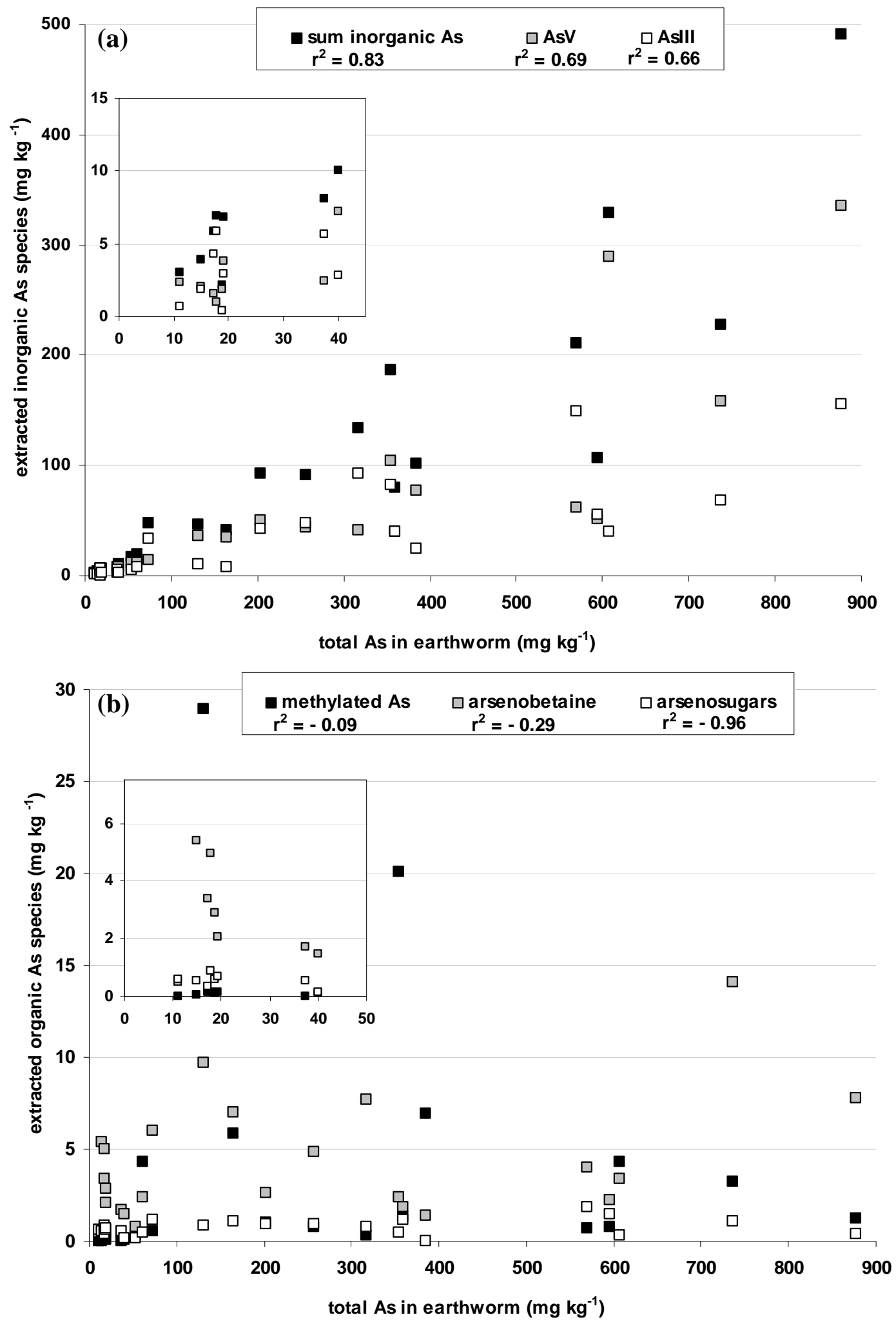

Figures 3a/b: Inorganic (a) and organic (b) As species extracted from earthworms plotted against increasing total As in earthworm. Methylated refers to the sum of $\mathrm{MA}^{\mathrm{V}}$ and $\mathrm{DMA}^{\mathrm{V}}$. Arsenosugars refers to the sum of sugars 1,2 and 4. 